\title{
FACTORS ASSOCIATED WITH MENARCHE AT SEVENTH GRADE STUDENTS IN JUNIOR HIGH SCHOOL
}

\author{
Neila Sulung ${ }^{1}$ Mentari Yellisia ${ }^{2 *}$ \\ Keperawatan STIKes Fort De Kock Bukittinggi \\ Mentari_yellisia@yahoo.com
}

Submitted: 28-08-2017, Reviewer: 12-09-2017, Accepted: 24-10-2017

\begin{abstract}
ABSTRAK
Menarche adalah perdarahan pertama dari uterus yang terjadi pada seorang wanita. Usia yang mendapat menarche bervariasi yaitu antara usia 10-16 tahun, rata-rata usia menarche di Indonesia adalah 13 tahun. Berdasarkan survey yang dilakukan terhadap siswi kelas VII di SMPN 1 Ampek Angkek terdapat siswi yang mengalami menarche pada usia kurang dari 10 tahun (20\%), 10 tahun (40\%), 11 tahun (10\%) dan 12 tahun (10\%). Penelitian ini bertujuan untuk mengetahui faktor-faktor yang mempengaruhi menarche pada siswi kelas VII di SMP Negeri 1

Ampek Angkek. Penelitian ini menggunakan metode deskriptif analitik dengan jenis penelitian kuantitatif dan pendekatan cross sectional. Populasi pada penelitian ini yaitu sebanyak 144 orang dan sampelnya 59 orang dan cara pengambilan sampel dengan menggunakan Metode Simple Random Sampling. Penelitian dilakukan pada bulan Januari 2017. Analisis data pada penelitian ini menggunakan distribusi frekuensi dan uji Chi-square. Hasil uji statistik menunjukkan adanya hubungan yang bermakna antara Indeks Massa Tubuh (IMT) $(\mathrm{p}=0,001)$ nilai OR 0,042, paparan media massa $(\mathrm{p}=0,018)$ nilai OR 6,039 dan aktivitas fisik $(\mathrm{p}=0,023)$ nilai $\mathrm{OR} 4,950$ dengan menarche pada siswi kelas VII di SMP Negeri 1 Ampek Angkek. Kesimpulan penelitian ini terdapat hubungan yang sangat bermakna antara Indeks Massa Tubuh (IMT) dengan menarche.
\end{abstract}

Kata Kunci : Siswi, Menarche

\begin{abstract}
Menarche is the first bleeding from the uterus that occur in a woman. The age of menarche varies the gain between the ages of 10-16 years, the average age of menarche in Indonesia is 13 years. Based on a survey conducted on students in seventh grade at Junior High School 1 Ampek Angkek there are girls who experience menarche at age less than 10 years (20\%), 10 years $(40 \%), 11$ years $(10 \%)$ and 12 years $(10 \%)$. This study aims to determine the factors affecting menarche in seventh grade students at Junior High School 1 Ampek Angkek. This study uses descriptive analytic methods to the type of quantitative and cross sectional approach. The population in this study as many as 144 people and the sample 59 people and a way of sampling using simple random sampling method. The study was conducted in January 2017. Analysis of the data in this study using frequency distribution and Chi -square test. Statistical analysis showed a significant relationship between Body Mass Index $(B M I)(p=0.001)$ value of OR 0.042 , mass media exposure $(\mathrm{p}=0.018)$ values OR 6,039 and physical activity $(\mathrm{p}=0.023)$ OR value 4,950 at menarche in seventh grade students at Junior High School 1 Ampek Angkek. The conclusion of this study is a highly significant correlation between Body Mass Index (BMI) with menarche. Suggested the need for health education to the students to maintain reproductive health, balanced nutrition and regular exercise.
\end{abstract}

Keyword : Students, Menarche 


\section{PENDAHULUAN}

Menarche adalah perdarahan pertama dari uterus yang terjadi pada seorang wanita. Usia yang mendapat menarche bervariasi yaitu antara usia 10-16 tahun, tetapi rata-rata 12,5 tahun. Statistik menunjukkan bahwa usia menarche dipengaruhi faktor keturunan, keadaan gizi dan kesehatan umum, perbaikan pelayanan kesehatan, lingkungan masyarakat. Studi epidemilogis mengungkapkan fenomena yang menunjukkan fakta bahwa usia menarche wanita di berbagai belahan dunia akhir-akhir ini semakin cepat (Fidrin et al., 2014).

Kini usia menarche telah bergeser ke usia yang lebih muda yang disebut dengan menarche dini, yaitu antara 10-11 tahun. Menurut Mundell (2005) dalam Reswari (2012) disebutkan bahwa obesitas pada anak perempuan membantu timbulnya pubertas dini. Timbulnya pubertas tersebut ditandai dengan terjadinya menarche. Dampak terjadinya menarche dini antara lain terhambatnya pertumbuhan, stress emosional dan peningkatan risiko terjadinya kanker payudara serta peningkatan Penyakit Menular Seksual (PMS) dan kehamilan yang tidak disengaja. Selain itu, juga dapat meningkatkan risiko kelainan kardiovaskuler (Reswari, 2012).

Usia menarche dapat bervariasi pada setiap individu dan wilayah. Usia menarche di Inggris rata-rata datang pada usia 13 tahun, sedangkan pada suku Bundi di Papua Nugini menarche dicapai pada usia 18 tahun. Dalam 100 tahun terakhir ini usia menarche telah bergeser ke usia yang lebih muda. Semmel weiss menyatakan bahwa 100 tahun yang lalu usia gadis-gadis Vienna pada waktu menarche berkisar antara 15-19 tahun. Sekarang usia gadis remaja pada waktu menarche bervariasi lebar, yaitu antara 10-16 tahun tetapi rata-rata 12,5 tahun. Menurut Brown menurunnya usia menarche itu sekarang disebabkan oleh keadaan gizi dan kesehatan umum yang membaik, dan berkurangnya penyakit menahun (Derina, 2011).

Penelitian Forrest \& Jocqueline, tahun 1993 di USA selama periode 6 tahun (19821988) menemukan terjadinya penurunan usia menarche dari 12 tahun 7 bulan menjadi 12 tahun 5 bulan. Penelitian Adadevoh et.all, tahun 1989 di Ghana menemukan penurunan usia menarche dari 14 tahun 11 bulan 19561965 menjadi 13 tahun 66 bulan 1966-1975 dan 13 tahun 26 bulan pada tahun 1988 (Meliyana, 2013).

Hasil Riset Kesehatan Dasar tahun 2010 menunjukkan rata-rata usia menarche di Indonesia adalah 13 tahun dengan usia menarche termuda di bawah 9 tahun dan tertua 20 tahun. Survei nasional menunjukkan rata-rata usia menarche kebanyakan wanita Indonesia adalah 12,96 tahun dengan penurunan 0,145 tahun per dekade. Kebanyakan anak perempuan Indonesia mendapatkan menstruasi pertamanya pada usia 12 tahun (31,33\%), 13 tahun $(31,30 \%)$, dan 14 tahun $(18,24 \%)$. Rata-rata usia menarche terendah berada di Yogyakarta $(12,45$ tahun) dan yang paling tinggi terdapat di Kupang $(13,86)$. Berdasarkan penelitian Amaliah, 2012 dari 13.550 responden di Indonesia sebesar 48,2\% sudah mengalami menarche pada usia rata-rata $12,39 \pm 1,08$ tahun (Fidrin et al., 2014).

Usia untuk mencapai fase terjadinya menarche dipengaruhi oleh banyak faktor antara lain faktor internal dan eksternal. Beberapa hasil penelitian terdahulu menunjukkan adanya penurunan usia 
menarche yang diduga berhubungan dengan faktor internal yaitu genetik dan faktor eksternal, yaitu status sosial ekonomi keluarga, status gizi, keadaan keluarga, tempat tinggal, kegiatan fisik atau aktivitas olahraga dan keterpaparan terhadap media massa orang dewasa (Aisya, 2016).

Perbaikan nutrisi akan berdampak pada penurunan usia menstruasi pertama. Menarche dini lebih cendrung ditemui pada wanita dengan status gizi yang baik. Hal ini dikarenakan status gizi mempengaruhi maturitas system endokrin. Status gizi dapat diinterprestasikan dari Indeks Masa Tubuh (IMT) seseorang (Reswari, 2012).

Indeks Massa Tubuh (IMT) adalah salah satu cara penilaian status gizi seseorang. Indeks Massa Tubuh (IMT) ditentukan oleh berat badan dan tinggi badan. Indeks Massa Tubuh (IMT) sangat mempengaruhi status gizi dalam kaitannya terhadap usia menarche. Hal ini disebabkan oleh adanya Adypocytederived hormone Leptin yang berasal dari lemak tubuh yang diduga dapat mempengaruhi masa awal pubertas. Peningkatan kronis kadar leptin dalam darah dapat menyebabkan peningkatan kadar LH. Peningkatan LH berhubungan dengan peningkatan estradiol dan awal menarche (Reswari, 2012). Jadi penurunan usia menarche berkaitan dengan peningkatan Indeks Massa Tubuh (IMT).

Perkembangan penggunaan media massa juga dapat mempengaruhi terjadinya menarche. Menurunnya usia kematangan seksual ini kiranya terjadi dihampir seluruh dunia, sehubungan dengan membaiknya gizi sejak masa kanak-kanak di satu pihak dan meningkatnya informasi melalui media massa atau hubungan antar orang di pihak lain
(Prastika, 2011). Ransangan-rangsangan yang kuat dari luar, misalnya berupa film-film seks (blue film), buku-buku bacaan dan majalahmajalah bergambar seks, godaan dan rangsangan dari kaum pria, pengamatan secara langsung terhadap perbuatan seksual atau coitus (Rahmah, 2016).

Rangsangan yang terus menerus, kemudian menuju hipotalamus dan selanjutnya menuju hipofise pars anterior, melalui sistem portal. Hipofise anterior mengeluarkan hormon spesifik. Kelenjer indung telur memproduksi hormon estrogen dan progesteron. Hormon spesifik yang dikeluarkan indung telur memberikan umpan balik ke pusat pancaindra dan otak serta kelenjer induk hipotalamus dan hipofise, sehingga mengeluarkan hormon berfluktuasi. Dengan keluarnya hormon tersebut mempengaruhi kematangan organ-organ reproduksi sehingga terjadi usia menarche yang lebih awal (Reswari, 2012).

Faktor lain yang berhubungan dengan kejadian menarche adalah aktivitas fisik seperti olahraga. Aktivitas fisik yang berat akan terjadi adaptasi endokrin dalam tubuh sehingga terjadi disfungsi hipotalamus, serta penghambatan pulsasi GnRH sehingga produksi FSH dan LH menurun dan hormon estrogen yang dihasilkan menurun sehingga organ reproduksi belum matang dengan sempurna dan terjadi keterlambatan menarche pada remaja putri (Mulyani et al., 2008).

Menarche dini juga dikaitkan dengan faktor resiko terjadinya gangguan kesehatan. Penurunan usia menarche akan berdampak pada kesehatan reproduksi wanita, khususnya kesehatan reproduksi remaja. Semakin cepat remaja mendapatkan menarche, maka akan semakin cepat mengenal kehidupan seksual 
dimulai dari munculnya ketertarikan pada lawan jenis, dorongan untuk mengetahui dan melakukan aktivitas seksual. Percepatan usia menarche juga dapat memperbesar peluang terjadinya hiperplasia endometrium, kanker uterus dan kanker payudara yang dihubungkan dengan menarche dini dengan alasan hormonal, dalam hal ini lebih didominasi oleh estrogen (Maulina, 2015).

Dari hasil survey awal yang dilakukan terhadap 10 orang siswi kelas VII di SMP Negeri 1 Ampek Angkek Kecamatan Ampek Angkek Kabupaten Agam pada tanggal 9 Januari 2017 terdapat 8 siswi (80\%) yang telah mengalami menstruasi diantaranya 2 orang siswi menarche pada usia kurang dari 10 tahun, 4 orang siswi menarche pada usia 10 tahun, 1 orang siswi menarche pada usia 11 tahun, dan 1 orang siswi menarche pada usia 12 tahun rata-rata siswi kelas VII di SMP Negeri 1 Ampek Angkek Kecamatan Ampek Angkek Kabupaten Agam berusia 12- 13 tahun.

Tujuan penelitian ini untuk mengetahui faktor-faktor yang berhubungan dengan menarche pada siswi kelas VII di SMP Negeri 1 Ampek Angkek Kecamatan Ampek Angkek Kabupaten Agam tahun 2017.

\section{METODE PENELITIAN}

Penelitian ini menggunakan deskriptif analitik dengan pendekatan cross sectional. Penelitian ini dilakukan di SMPN 1 Ampek Angkek Kecamatan Ampek Angkek Kabupaten Agam waktu penelitian dilakukan pada bulan Januari tahun 2017. Subjek dalam penelitian ini adalah seluruh siswi kelas VII di SMPN 1 Ampek Angkek sebanyak 144 orang. Jumlah sampel dalam penelitian Ini ada sebanyak 59 orang siswi dengan teknik pengambilan sampel secara acak sederhana (Simple Random Sampling).

\section{HASIL DAN PEMBAHASAN}

Indeks Massa Tubuh (IMT)

Tabel 1 Distribusi frekuensi responden berdasarkan Indeks Massa Tubuh (IMT) di SMP N 1 Ampek Angkek Kecamatan Ampek Angkek Kabupaten Agam Tahun 2017

\begin{tabular}{cccc}
\hline No & Indeks Massa Tubuh (IMT) & f & \% \\
\hline 1 & Kurang & 29 & 49,2 \\
2 & Baik & 30 & 50,8 \\
\hline & Total & $\mathbf{5 9}$ & $\mathbf{1 0 0}$ \\
\hline
\end{tabular}

Penelitian ini dilakukan pada siswi kelas VII di SMP N 1 Ampek Angkek Kecamatan Ampek Angkek Kabupaten Agam tahun 2017 dan didapatkan bahwa dari 59 responden terdapat separoh responden yang memiliki Indeks Massa Tubuh (IMT) yang baik sebanyak 30 responden (50,8\%).

Indeks Massa Tubuh (IMT) merupakan alat yang sederhana untuk memantau status gizi orang, khususnya yang berkaitan dengan kekurangan dan kelebihan berat badan. Indeks Massa Tubuh (IMT) merupakan cara termudah untuk memperkirakan obesitas serta berkolerasi tinggi dengan masa lemak tubuh. Untuk mengetahui Indeks Massa Tubuh (IMT) ini dapat dihitung dengan rumus metrik yaitu berat badan $(\mathrm{kg})$ dibagi tinggi badan $(\mathrm{m})$ di kuadratkan (Kemenkes RI, 2014).

Penelitian ini tidak sejalan dengan penelitian yang dilakukan oleh Natalia (2015) tentang faktor-faktor yang berhubungan dengan status menarche di SMP X di Rangkabitung ditemukan bahwa dari 106 siswi terdapat $84 \%$ siswi yang memiliki Indeks Massa Tubung (IMT) yang baik. Sedangkan penelitian yang dilakukan oleh Reswari (2012) tentang hubungan indeks massa tubuh (IMT) dengan usia menarche 
pada siswi Sekolah Dasar Ngoresan Surakarta, ditemukan bahwa dari 43 siswi terdapat 30,23\% siswi yang memiliki Indeks Massa Tubuh (IMT) yang normal. Penelitian ini tidak sejalan dengan penelitian yang telah penulis lakukan.

Menurut asumsi peneliti Indeks Massa Tubuh (IMT) adalah salah satu cara penilaian status gizi seseorang, Indeks Massa Tubuh (IMT) ditentukan oleh berat badan dan tinggi badan. Indeks Massa Tubuh (IMT) yang baik pada siswi karena asupan nutrisi yang dikonsumsinya sudah memenuhi kebutuhan gizi yang seimbang sehingga kadar lemak dalam tubuh menjadi lebih banyak atau meningkat yang dapat mempengaruhi berat badan dan tinggi badan seseorang.

Begitu juga dengan siswi yang memiliki Indeks Massa Tubuh (IMT) yang kurang dapat dikarenakan oleh berbagai faktor seperti sosial ekonomi yang rendah, asupan gizi yang kurang atau tidak seimbang dan dapat juga disebabkan oleh faktor keturunan. Hasil penelitian yang dilakukan oleh peneliti lain yang tidak sejalan dengan peneliti lakukan karena adanya perbedaan pada jumlah sampel dan populasi pada penelitian ini.

\section{Paparan media massa}

Tabel 2 Distribusi frekuensi responden berdasarkan paparan media massa di SMP N 1 Ampek Angkek Kecamatan Ampek Angkek Kabupaten Agam Tahun 2017

\begin{tabular}{cccc}
\hline No & Paparan Media Massa & f & $\mathbf{\%}$ \\
\hline 1 & Terpapar & 31 & 52,5 \\
2 & Tidak Terpapar & 28 & 47,5 \\
\hline & Total & $\mathbf{5 9}$ & $\mathbf{1 0 0}$ \\
\hline
\end{tabular}

Penelitian ini dilakukan pada siswi kelas VII di SMP N 1 Ampek Angkek Kecamatan Ampek Angkek Kabupaten Agam tahun 2017 dan didapatkan bahwa dari 59 responden lebih dari separoh responden yang terpapar terhadap media massa sebanyak 31 responden $(52,5 \%)$

Tidak tersedianya informasi akurat dan benar tentang kesehatan reproduksi memaksa remaja mencari akses dan melakukan eksplorasi sendiri. Arus komunikasi dan informasi mengalir deras menawarkan petualangan yang menantang. Majalah buku, dan film porno yang memaparkan kenikmatan hubungan seksual tanpa mengajarkan tanggung jawab yang harus disandang dan resiko yang harus dihadapi menjadi acuan utama mereka. Mereka juga melalap pelajaran seks dari internet meski saat ini aktivitas situs pornografi baru sekitar 2-3\% dan sudah muncul situs-situs pelindung dari pornografi (Prastika, 2011).

Penelitian ini tidak sejalan dengan penelitian yang dilakukan oleh Natalia (2015) tentang faktor-faktor yang berhubungan dengan status menarche di SMP X di Rangkasbitung ditemukan bahwa dari 106 siswi terdapat $70,8 \%$ siswi yang terpapar terhadap media massa. Sedangkan penelitian yang dilakukan oleh Kisswardhani (2014) tentang hubungan antara status gizi, tingkat paparan media massa dan faktor keturunan dengan usia menarche pada siswi di SMP Negeri 1 Subah Kabupaten Batang ditemukan bahwa dari 59 balita terdapat 47,5\% siswi yang terpapar terhadap media massa. Penelitian ini sejalan dengan penelitian yang telah penulis lakukan.

Menurut asumsi peneliti paparan media massa adalah sebagai akibat kemajuan teknologi dan informasi serta dampak kemajuan globalisasi yang sangat pesat, sehingga sangat besar pengaruhnya terhadap 
perilaku masyarakat yang khususnya pada remaja. Siswi yang terpapar terhadap media massa merupakan akibat meningkatnya penyebaran informasi dan rangsangan seksual melalui media massa elektronik sepeti televisi, VCD, bioskop, internet, handphone dan lainlain misalnya siswi pernah membuka internet untuk menonton video orang dewasa, pernah membaca komik dengan gambar yang memperlihatkan wanita atau laki-laki dengan pakaian terbuka/ minim/ tanpa busana dan melihat gambar wanita atau laki-laki berpakaian minim dan terbuka di majalah/ video klip/ buku/ film/ TV/ iklan. Hal tersebut terjadi karena filter masyarakat terhadap televisi dan internet belum kuat serta banyak orang tua tidak punya pedoman dalam mengawasi anaknya menonton, penggunaan internet dan handphone. Hasil penelitian yang dilakukan oleh peneliti lain yang tidak sejalan dengan peneliti lakukan karena adanya perbedaan pada jumlah sampel dan populasi pada penelitian ini.

\section{Aktivitas fisik}

Tabel 3 Distribusi frekuensi responden berdasarkan aktivitas fisik di SMP N 1 Ampek Angkek Kecamatan Ampek Angkek Kabupaten Agam Tahun 2017

\begin{tabular}{cccc}
\hline No & Aktivitas Fisik & f & \% \\
\hline 1 & Ringan & 38 & 64,4 \\
2 & Berat & 21 & 35,6 \\
\hline & Total & $\mathbf{5 9}$ & $\mathbf{1 0 0}$ \\
\hline
\end{tabular}

Penelitian ini dilakukan pada siswi kelas VII di SMP N 1 Ampek Angkek Kecamatan Ampek Angkek Kabupaten Agam tahun 2017 dan didapatkan bahwa dari 59 responden lebih dari separoh responden yang memiliki aktivitas fisik ringan sebanyak 38 responden $(64,4 \%)$.
Aktivitas fisik adalah setiap gerakan tubuh yang dihasilkan oleh otot rangka yang memerlukan pengeluaran energi. Aktivitas fisik yang tidak ada (kurangnya aktivitas fisik) merupakan faktor risiko independen untuk penyakit kronis, dan secara keseluruhan diperkirakan menyebabkan kematian secara global. Aktivitas fisik dapat digolongkan menjadi tiga tingkatan (1) kegiatan ringan; hanya memerlukan sedikit tenaga dan biasanya tidak menyebabkan perubahan dalam pernapasan atau ketahanan (endurance), (2) kegiatan sedang; membutuhkan tenaga intens atau terus menerus, gerakan otot yang berirama atau kelenturan (flexibility) dan (3) kegiatan berat; biasanya berhubungan dengan olahraga dan membutuhkan kekuatan (strength), membuat berkeringat (Mulyani et al., 2008).

Penelitian ini tidak sejalan dengan penelitian yang dilakukan oleh Fidrin et al (2014) tentang faktor yang berhubungan dengan usia menarche pasa siswi SMP Negeri 3 Sumbul ditemukan bahwa dari 126 siswi terdapat $61,1 \%$ siswi yang memiliki aktivitas fisik sedang dan 9,5\% siswi yang memiliki aktivitas fisik berat. Sedangkan penelitian yang dilakukan oleh Wulandari \& Ungsianik (2013) tentang status gizi, aktivitas fisik dan usia menarche remaja putri ditemukan bahwa dari 87 siswi terdapat $82,8 \%$ siswi yang memiliki aktivitas ringan dan $17,2 \%$ siswi yang memiliki aktivitas berat. Penelitian ini sejalan dengan penelitian yang telah penulis lakukan.

Menurut asumsi peneliti aktivitas fisik adalah gerakan fisik yang dilakukan oleh otot tubuh yang memerlukan pengeluaran energi. Aktivitas fisik dikatakan berat apabila nilai Physical Activity Level (PAL) $\leq 1.90$ dan $\leq$ 
2.40 dan Aktivitas fisik dikatakan ringan apabila nilai Physical Activity Level (PAL) s 1.40 dan $\leq 1.89$. Aktivitas fisik siswi yang dikatakan berat apabila siswi melakukan aktivitas fisik olahraga seperti volli, bulutangkis dan berenang yang rutin dilakukan dan dalam durasi waktu yang lama. Aktivitas fisik siswi yang dikatakan ringan apabila siswi melakukan aktivitas fisik seperti tidur, duduk, mendengarkan music, makan, ibadah, menyci piring dan menonton TV. Semakin berat aktivitas fisik akan semakin besar energy yang akan dikeluarkan begitu juga jika semakin lama aktivitas yang dilakukan maka akan memberi dampak pada nilai Physical Activity Level (PAL) yang akan dihasilkan. Hasil penelitian yang dilakukan oleh peneliti lain yang tidak sejalan dengan peneliti lakukan karena adanya perbedaan pada jumlah sampel dan populasi pada penelitian ini.

\section{Menarche}

Tabel 4 Distribusi frekuensi menarche pada Siswi Kelas VII di SMP N 1 Ampek Angkek Kecamatan Ampek Angkek Kabupaten Agam Tahun 2017

\begin{tabular}{cccc}
\hline No & Menarche & f & \% \\
\hline 1 & Sudah & 45 & 76,3 \\
2 & Belum & 14 & 23,7 \\
\hline & Total & $\mathbf{5 9}$ & $\mathbf{1 0 0}$ \\
\hline
\end{tabular}

Penelitian ini dilakukan pada siswi kelas VII di SMP N 1 Ampek Angkek Kecamatan Ampek Angkek Kabupaten Agam tahun 2017 dan didapatkan bahwa dari 59 responden lebih dari separoh responden yang sudah mengalami menarche sebanyak 45 responden $(76,3 \%)$.

Menarche merupakan puncak dari rangkaian peristiwa yang kompleks yang meliputi pematangan aksis hipotalamushipofisis-ovarium (H-H-O) untuk memproduksi ovum atau endometrium matang sehingga dapat menunjang zigot jika terjadi pembuahan (Heffner \& Schust, 2008). Menarche juga disebut siklus menstruasi pertama sekali yang dialami wanita. Menarche terjadi akibat peningkatan FSH dan LH yang merangsang sel target ovarium. FSH dan LH berkombinasi dengan reseptor $\mathrm{FSH}$ dan $\mathrm{LH}$ yang selanjutnya akan meningkatkan laju kecepatan sekresi, pertumbuhan dan proliferasi sel (Derina, 2011).

Penelitian ini tidak sejalan dengan penelitian yang dilakukan oleh Reswari (2012) tentang hubungan indeks massa tubuh (IMT) dengan usia menarche pada siswi Sekolah Dasar Ngoresan Surakarta, ditemukan bahwa dari 43 siswi terdapat $27,91 \%$ siswi yang sudah mengalami menarche. Sedangkan penelitian yang dilakukan oleh Sumini (2014) tentang hubungan status gizi dengan usia menarche pada siswi Sekolah Dasar Kelas 4,5, dan 6 di Sekolah Dasar Negeri Grabahan Kecamatan Karangrejo Kabupaten Mangetan ditemukan bahwa dari 45 orang siswi terdapat $71 \%$ siswi yang sudah mengalami menarche. Penelitian ini sejalan dengan penelitian yang telah penulis lakukan.

Menurut asumsi peneliti banyak hal yang mempengaruhi menarche pada remaja putri, antara lain faktor internal dan eksternal. Faktor internal yaitu genetik dan faktor eksternal, yaitu status sosial ekonomi keluarga, status gizi, keadaan keluarga, tempat tinggal, kegiatan fisik atau aktivitas olahraga dan keterpaparan terhadap media massa orang dewasa. Maka faktor-faktor inilah yang akan mengakibatkan sinyal neurotransmittier dan neuropeptide di hipotalamus merangsang 
hipofisis anterior untuk menghasilkan hormon FSH dan LH, kemudian hormon tersebut menuju ovarium untuk menghasilkan hormon estrogen yang akan mempengaruhi kematangan dari organ reproduksi wanita dan berdampak pada status menarche dari seseorang. Hasil penelitian yang dilakukan oleh peneliti lain yang tidak sejalan dengan peneliti lakukan karena adanya perbedaan pada jumlah sampel dan populasi pada penelitian ini.

\section{Analisis Bivariat}

Tabel 5 Hubungan Indeks Massa Tubuh (IMT) dengan Menarche pada Siswi Kelas VII di SMP N 1 Ampek Angkek Kecamatan Ampek Angkek Kabupaten AgamTahun 2017

\begin{tabular}{|c|c|c|c|c|c|c|c|c|}
\hline \multirow{3}{*}{$\begin{array}{l}\text { Indeks } \\
\text { Massa } \\
\text { Tubuh } \\
\text { (IMT) }\end{array}$} & \multicolumn{4}{|c|}{ Menarche } & \multicolumn{2}{|c|}{ Total } & \multirow{3}{*}{$\begin{array}{c}\text { p } \\
\text { val } \\
\text { ue } \\
0,00\end{array}$} & \multirow{3}{*}{$\begin{array}{c}\text { OR } \\
(\mathbf{C I} \\
\mathbf{9 5 \%}) \\
0,042\end{array}$} \\
\hline & \multicolumn{2}{|c|}{ Sudah } & \multicolumn{2}{|c|}{ Belum } & & & & \\
\hline & $\mathbf{n}$ & $\%$ & n & $\%$ & n & $\%$ & & \\
\hline Kurang & 16 & 55,2 & 13 & 44,8 & 29 & 100 & 1 & $(0,005$ \\
\hline Baik & 29 & 96,7 & 1 & 3,3 & 30 & 100 & & $-0,355$ \\
\hline \multicolumn{2}{|c|}{ Total } & 45 & 76,3 & 14 & 23,7 & 59 & 100 & \\
\hline
\end{tabular}

Hasil uji statistik diperoleh nilai $\mathrm{p}=$ 0,001 ( $<<0,05$ ), maka dapat disimpulkan ada hubungan yang bermakna secara statistik antara Indeks Massa Tubuh (IMT) dengan menarche dengan nilai $\mathrm{OR}=0,042$ artinya responden yang memiliki Indeks Massa Tubuh (IMT) kurang 0,042 kali sudah mengalami menarche.

Penelitian ini sejalan dengan hasil penelitian yang dilakukan oleh Natalia (2015) tentang faktor-faktor yang berhubungan dengan status menarche di SMP X di Rangkabitung terdapat $98,88 \%$ siswi yang memiliki Indeks Massa Tubuh (IMT) baik yang sudah mengalami menarche. Dan terdapat hubungan antara Indeks Massa Tubuh (IMT) dengan menarche dengan nilai $\mathrm{p}=0,00$. Sedangkan penelitian yang dilakukan oleh Reswari (2012) tentang hubungan indeks massa tubuh (IMT) dengan usia menarche pada siswi Sekolah Dasar Ngoresan Surakarta ditemukan bahwa dari 43 orang siswi ada 13 siswi yang memiliki Indeks Massa Tubuh (IMT) normal dengan 7 siswi yang sudah mengalami menarche. Dan pada penelitian ini terdapat hubungan antara Indeks Massa Tubuh (IMT) dengan menarche dengan nilai $\mathrm{p}=0,001$. Penelitian ini sejalan dengan penelitian yang telah penulis lakukan.

Menurut asumsi peneliti Indeks Massa Tubuh (IMT) sangat mempengaruhi status gizi dalam kaitannya terhadap usia menarche. Asupan gizi yang kurang pada seseorang akan berdampak pada penurunan fungsi reproduksi, dimana produksi hormon estrogen untuk pertumbuhan dan pelepasan endometrium vang dihasilkan tidak mencukuni sehingga encometrium belum matang secara sempurna dan mengakibatkan keterlambatan menarche. Hasil penelitian yang telah dilakukan terdapat lebih dari separoh siswi yang memiliki Indeks Massa Tubuh (IMT) yang baik yang telah mengalami menarche. Gizi mempengaruhi kematangan seksual pada remaja yang mendapat menarche lebih dini. Pada umumnya, mereka yang mengalami menarche dini akan memiliki Indeks Masa Tubuh (IMT) yang lebih tinggi dan mereka yang matang terlambat memiliki IMT lebih kecil pada usia yang sama. 
Tabel 6 Hubungan paparan media massa

dengan menarche pada Siswi Kelas VII di SMP N 1 Ampek Angkek Kecamatan Ampek Angkek Kabupaten Agam Tahun 2017

\begin{tabular}{|c|c|c|c|c|c|c|c|c|}
\hline \multicolumn{2}{|c|}{ Paparan } & \multicolumn{3}{|c|}{ Menarche } & & \multirow{2}{*}{$\begin{array}{c}\mathbf{p} \\
\text { value }\end{array}$} & \multirow{2}{*}{$\begin{array}{c}\text { OR } \\
\text { (CI } \\
\mathbf{9 5 \% )}\end{array}$} \\
\hline \multirow[t]{2}{*}{$\begin{array}{l}\text { Media } \\
\text { Massa }\end{array}$} & \multicolumn{2}{|c|}{ Sudah } & \multicolumn{2}{|c|}{ Belum } & & otal & & \\
\hline & & $n$ & $\%$ & $\mathbf{n}$ & $\%$ & $\mathbf{n}$ & $\%$ & 0,018 \\
\hline 6,039 & & & & & & & & \\
\hline Terpapar & 28 & 90,3 & 3 & 9,7 & 31 & 100 & & $(1,472$ \\
\hline $\begin{array}{l}\text { Tidak } \\
\text { terpapar }\end{array}$ & 17 & 60,7 & 11 & 39,3 & 28 & 100 & & $\begin{array}{c}- \\
24,778\end{array}$ \\
\hline Total & & 45 & 76,3 & 14 & 23,7 & 59 & 100 & \\
\hline
\end{tabular}

Hasil uji statistik diperoleh nilai $\mathrm{p}=$ 0,018 ( $\mathrm{p}<0,05$ ), maka dapat disimpulkan ada hubungan yang bermakna secara statistik antara paparan media massa dengan menarche dengan nilai $\mathrm{OR}=6,039$ artinya responden yang terpapar terhadap media massa 6,039 kali sudah mengalami menarche.

Penelitian ini tidak sejalan dengan hasil penelitian yang dilakukan oleh Natalia (2015) tentang faktor-faktor yang berhubungan dengan status menarche di SMP $X$ di Rangkabitung terdapat $90,67 \%$ siswi yang terpapar oleh media massa yang sudah mengalami menarche. Dan tidak terdapat hubungan antara paparan media massa dengan menarche dengan nilai $\mathrm{p}=0,111$. Sedangkan penelitian yang dilakukan oleh Prastika (2011) tentang hubungan keterpaparan media massa pada siswi kelas V SD dengan usia menarche di empat SD Kecamatan Tanjung Gadang terdapat 96,8\% siswi yang terpapar oleh media massa yang mengalami menarche dini dan terdapat hubungan antara paparan media massa dengan menarche dengan nilai $\mathrm{p}=$ 0,037 . Penelitian ini sejalan dengan penelitian yang telah penulis lakukan.
Menurut asumsi peneliti paparan media massa dapat mempengaruhi cepat atau lambatnya menarche pada remaja putri. Remaja putri yang terpapar media massa yang berkonten pornografi akan mempercepat datangnya menarche karena rangsanganrangsangan berupa film-film seks (blue film), buku-buku bacaan dan majalah-majalah bergambar seks, godaan dan rangsangan dari kaum pria dan pengamatan secara langsung terhadap perbuatan seksual akan masuk ke pusat pancaindra diteruskan melalui striae terminalis menuju pusat yang disebut pubertas inhibitor. Sedangkan remaja putri yang tidak terpapar oleh media massa namun sudah mengalami menarche diusia yang lebih muda atau menarche dini dapat disebabkan oleh faktor lain seperti status gizi yang baik, ekonomi yang tinggi keturunan, aktivitas fisik yang ringan dan psikologis remaja.

Tabel 7 Hubungan aktivitas fisik dengan menarche pada Siswi Kelas VII di SMP N 1 Ampek Angkek Kecamatan Ampek Angkek Kabupaten Agam Tahun 2017

\begin{tabular}{|c|c|c|c|c|c|c|c|c|}
\hline \multirow{3}{*}{$\begin{array}{c}\text { Aktivi } \\
\text { tas } \\
\text { fisik }\end{array}$} & \multicolumn{4}{|c|}{ Menarche } & \multirow{2}{*}{\multicolumn{2}{|c|}{ Total }} & \multirow{2}{*}{$\begin{array}{c}\mathbf{p} \\
\text { value }\end{array}$} & \multirow{2}{*}{$\begin{array}{r}\text { OR } \\
\text { (CI } \\
95 \%)\end{array}$} \\
\hline & \multicolumn{2}{|c|}{ Sudah } & \multicolumn{2}{|c|}{ Belum } & & & & \\
\hline & $\mathbf{n}$ & $\%$ & $\mathrm{n}$ & $\%$ & $\mathbf{n}$ & $\%$ & 0,023 & 4,950 \\
\hline Ringan & 33 & 86,8 & 5 & 13,2 & 38 & 100 & & $(1,380$ \\
\hline Berat & 12 & 57,1 & 9 & 42,9 & 21 & 100 & & - \\
\hline Total & 45 & 76,3 & 14 & 23,7 & 59 & 100 & & 17,756 \\
\hline
\end{tabular}

Hasil uji statistik diperoleh nilai $\mathrm{p}=$ 0,023 ( $\mathrm{p}<0,05$ ), maka dapat disimpulkan ada hubungan yang bermakna secara statistik antara aktivitas fisik dengan menarche dengan nilai $\mathrm{OR}=4,950$ artinya responden yang memiliki aktivitas ringan4,950 kali sudah mengalami menarche. 
Penelitian ini tidak sejalan dengan hasil penelitian yang dilakukan oleh Fidrin et al., (2014) tentang faktor yang berhubungan dengan usia menarche pasa siswi SMP Negeri 3 Sumbul terdapat $24,3 \%$ siswi yang memiliki aktivitas fisik ringan yang mengalami menarche cepat dan $75,7 \%$ siswi yang mengalami menarche normal, dan tidak terdapat hubungan antara aktivitas fisik dengan usia menarche dengan nilai $\mathrm{p}=0,65$. Sedangkan penelitian yang dilakukan oleh Natalia (2015) tentang faktor-faktor yang berhubungan dengan status menarche di SMP $\mathrm{X}$ di Rangkabitung terdapat $86,5 \%$ siswi yang memiliki aktivitas fisik ringan yang sudah mengalami menarche, dan tidak terdapat hubungan antara aktivitas fisik dengan menarche dengan nilai $\mathrm{p}=1,00$. Penelitian ini tidak sejalan dengan penelitian yang telah penulis lakukan.

Menurut asumsi peneliti adanya hubungan yang bermakna antara aktivitas fisik dengan menarche karena aktivitas fisik yang berat menyebabkan aktivitas ovarium menurun sehingga kadar estrogen lebih rendah dimana estrogen sangat dibutuhkan dalam proses menarche. Selain itu aktivitas fisik teratur atau rutin atau melakukan aktivitas fisik yang berat akan membakar lemak di dalam tubuh, dimana seseorang yang mempunyai kadar lemak yang sedikit didalam tubuh akan memperlambat usia menarche. Sedangkan seseorang yang memiliki aktivitas fisik ringan akan memiliki kadar lemak didalam tubuh yang banyak dan melebihi dari yang diperlukan untuk fungsi tubuh yang normal maka akan terjadi penimbunan lemak, sehingga mengakibatkan berat badan yang lebih dari normal dan hormon yang dibentuk oleh lemak akan memacu menstruasi datang lebih cepat atau lebih dini. Pada siswi yang memiliki aktivitas fisik yang ringan maka aktivitas pematangan endomatriumnya akan lebih cepat dan akan menyebabkan menarche yang lebih cepat pula, karena seseorang yang memiliki aktivitas fisik yang ringan cenderung memiliki kadar lemak dalam tubuh yang banyak. Remaja putri yang memiliki aktivitas fisik berat namun sudah mengalami menarche diusia yang lebih muda atau menarche dini dapat disebabkan oleh faktor lain seperti status gizi yang baik, ekonomi yang tinggi keturunan, terpapar media massa, dan psikologis remaja.

\section{SIMPULAN}

Hasil penelitian ini terlihat hubungan yang bermakna secara statistik antara Indeks Massa Tubuh (IMT) dengan menarche pada siswi kelas VII di SMP N 1 Ampek Angkek Kecamatan Ampek Angkek Kebupaten Agam tahun 2017 dengan $p$-value sebesar $0,001(\mathrm{p}<0,05)$ dan nilai $\mathrm{OR}=0,042$. 6 . Ada hubungan yang bermakna secara statistik antara paparan media massa dengan menarche pada siswi kelas VII di SMP N 1 Ampek Angkek Kecamatan Ampek Angkek Kebupaten Agam tahun 2017 dengan $p$-value sebesar 0,018 ( $\mathrm{p}<$

$0,05)$ dan nilai $\mathrm{OR}=, 039$.

Ada hubungan yang bermakna secara statistik antara aktivitas fisik dengan menarche pada siswi kelas VII di SMP N 1 Ampek Angkek Kecamatan Ampek Angkek Kebupaten Agam tahun 2017 dengan $p$-value sebesar 0,023 (p $<0,05)$ dan nilai $\mathrm{OR}=4,950$. Bagi responden atau siswi kelas VII Diharapkan siswi lebih mengetahui tentang menstruasi dan hal-hal apa saja yang harus dilakukan saat menghadapi menstruasi. 


\section{DAFTAR PUSTAKA}

Aisya, M. (2016). Hubungan Gaya Hidup dengan Kejadian Menarche Di SMA Negeri 1 Driyorejo Kabupaten Gresik. Universitas Airlangga.

Derina, K. A. (2011). Faktor-faktor Yang Berhubungan Dengan Usia Menarche Pada Remaja Putri Di SMP 155 Jakarta Tahun 2011. Universitas Islam Negeri Syarif Hidayatullah Jakarta.

Dewi, A. P. (2012). Hubungan Karakteristik Remaja, Peran Teman Sebaya dan Paparan Pornografi dengan Perilaku Seksual Remaja Di Kelurahan Pasir Gunung Selatan Depok. Universitas Indonesia.

Fajria, L., \& Desi, N. M. (2014). Gambaran Faktor Penyebab Menarche Dini Pada Siswi SMPN 4 Kota Pariaman. Ners Jurnal Keperawatan, 10(1), 11-19.

Fidrin, Muda, S., \& Hiswani. (2014). Faktor Yang Berhubugan Dengan Usia Menarche Pada Siswi SMP Negeri 3 Sumbul Tahun 2014. Kesehatan Masyarakat USU.

Fitriyah, N., \& Ruhyana. (2015). Faktorfaktor Yang Mempengaruhi Menarche Pada Siswi SMP Muhammadiyah 3 Yogyakarta. Sekolah Tinggi Ilmu Kesehatan 'Aisyiyah Yogyakarta.

Hardiningsih, A., \& Kusharisupeni. (2013). Faktor-faktor yang Berhubungan dengan Status Menarche pada Siswi Sekolah Dasar (SD) dan Sekolah Menengah Pertama (SMP) Islam As-Syafi'iyah Bekasi Tahun 2013. Universitas Indonesia.

Heffner, L. J., \& Schust, D. J. (2008). At a Glance Sistem Reproduksi. (A. Safitri, Ed.) (2nd ed.). Jakarta: Erlangga.

Kemenkes RI. (2010). Riset Kesehatan
Dasar.

Jakarta: Kementrian Kesehatan RI.

Kemenkes RI. (2012). Pusat Data Dan

Informasi Kementerian Kesehatan RI Situasi Kesehatan Reproduksi Remaja. Jakarta: Kemenkes RI.

Kemenkes RI. (2014). Pedoman Gizi Seimbang. Jakarta: Kementrian Kesehatan RI.

Kisswardhani, A. D. (2014). Hubungan Antara Status Gizi, Tingkat Paparan Media Massa dan Faktor Keturunan dengan Usia Menarche pada Siswi Di SMP Negeri 1 Subah Kabupaten Batang. Universitas Muhammadiyah Surakarta.

Kusmiran, E. (2013). Kesehatan Reproduksi Remaja Dan Wanita. (P. P. Lestari, Ed.). Jakarta: Salemba Medika.

Manuaba, I. A. C., Manuaba, I. B. G. F., \& Manuaba, I. B. . (2013). Gawat Darurat Obstetri Genekologi \& Obstetri Genekologi Sosial Untuk Profesi Bidan. (M. Ester, Ed.). Jakarta: EGC.

Manuaba, I. A. S. K. D. S., Manuaba, I. A. C., Manuaba, I. B. G. F., \& Manuaba, I. B. . (2010). Buku Ajar Genekologi Untuk Mahasiswa Kebidanan. (M. Ester, Ed.). Jakarta: EGC.

Maulina, A. (2015). Hubungan Antara Status Gizi dan Aktivitas Fisik dengan Usia Menarche pada Remaja Putri Di SMP Negeri 21 Padang Tahun 2015.Universitas Andalas.

Meliyana, E. (2013). Hubungan Indeks Massa Tubuh dan Paparan Media Massa denga Usia Menarche pada Siswi Kelas VII Di SMP Jaya Suti Abadi Tambun Bekasi Tahun 2011, 2-4.

Mulyani, S., Yusuf, S. A., Kiyatno, Wahjono, 
S., \& Probandari, A. (2008). Aktivitas

Sisik Intensitas Tinggi Sebagai Faktor Resiko Terhadap Gangguan Siklus Menstruasi. Universitas Sebelas Maret.

Munda, S. S., Wagey, F. W., \& Wantania, J. (2012). Hubungan Antara IMT dengan Usia Menarche pada Siswi SD dan SMP Di Kota Manado. Universitas Sam Ratulangi.

Natalia, S. E. (2015). Faktor-faktor yang Berhubungan dengan Status Menarche di SMP X di Rangkabitung. COPING Ners Journal, 3(2), 34-43.

Notoatmodjo, S. (2010). Metodologi Penelitian Kesehatan. Jakarta: Rineka Cipta.

Prastika, S. (2011). Hubungan Keterpaparan Media Massa Pada Siswi Kelas V SD dengan Usia Menarche Di Empat SD Kecamatan Tanjung Gadang Tahun 2011. Sekolah Tinggi Ilmu Kesehatan Fort De Kock Bukittinggi.

Rahmah, U. F. (2016). Gambaran Keterpaparan Media Massa Berkonten Pornografi pada Usia Menarche Di Wilayah Kecamatan Pancoran MasDepok. Universitas Islam Negeri Syarif Hidayatullah.

Reswari, A. A. (2012). Hubungan Indeks Massa Tubuh (IMT) dengan Usia Menarche pada Siswi Sekolah Dasar Ngoresan Surakarta. Universitas Sebelas Maret.

Setyowati, F. W. (2007). Hubungan Indeks Massa Tubuh $\geq 20$ dengan Usia Menarche pada Siswi Sekolah Dasar Di Seluruh Kecamatan Patrang Kabupaten Jember. Universitas Jember.

Siswianti, Y. A. (2012). Hubungan Berat Badan, Persen Lemah Tubuh, Status Gizi (IMT/U), Umur Menarche Ibu dengan Umur Menarche pada Siswi Di
SDN Cikaret 01 Cibinong Kabupaten

Bogor Tahun 2012. Universitas Indonesia.

Siwi, I. M. (2015). Hubungan Indeks Massa Tubuh dengan Usia Menarche pada SIswi SMP N 2 Purwosari Kabupaten Gunungkidul Yogyakarta. Sekolah Tinggi Ilmu Kesehatan 'Aisyiyah Yogyakarta.

Sofya, S. N. Y. (2015). Hubungan Aktivitas Fisik dengan Usia Menarche pada Remaja Putri Atlet dan Non Atlet. Institut Pertanian Bogor.

Sudibjo, P., Arovah, N. I., \& Lakmi A, R. (2013). Tingkat Pemahaman dan Survei Level Aktivitas Fisik, Status Kecukupan Energi dan Status Antropomertik Mahasiswa Program Studi Pendidikan Kepelatihan Olahraga FIK UNY. MEDIKORA, XI(2), 183203.

Sumini. (2014). Hubungan Status Gizi dengan Usia Menarche pada Siswi Sekolah Dasar Kelas 4, 5 dan 6 di Sekolah Dasar Negeri Grabahan Kecamatan Karangrejo Kabupaten Magetan. Jurnal Delima Harapan, $3(2), 1-9$.

Susanti, E. (2012). Hubungan Status Gizi Terhadap Usia Menarche Pada Remaja Putri Usia 10-16 Tahun Di SMP 1 Baso. Jurnal Kesehatan STIKes Prima Nusantara Bukittinggi, 3(1), 1-5.

Sylvia, \& Saftarina, F. (2012). Hubungan Status Gizi dengan Usia Menarche pada Remaja Putri di SMP Negeri 22 Bandar Lampung. MAJORITY (Medical Journal of Lampung University), (ISSN 23373776), 18-23. https://doi.org/ISSN 23373776

Warita, P. (2009). Gambaran Usia Menarche 
pada Remaja Putri Di SMP Shafiyyatul Amaliyyah dan SMP Nurul Hasanah Kota Medan Tahun 2009. Universitas Sumatra Utara.

Wong, D. L., Eaton, M. H., Wilson, D., Winkelstein, M. L., \& Schwartz, P. (2009). Buku Ajar Keperawatan Pediatrik. (E. K. Yudha, D. Yulianti, N. B. Subekti, E. Wahyuningsih, \& M. Ester, Eds.) (6th ed.). Jakarta: EGC.

Wulandari, S., \& Ungsianik, T. (2013). Status Gizi, Aktivitas Fisik, dan Usia Menarche Remaja Putri. Jurnal Keperawatan Indonesia, 16(1), 55-59. 